\title{
STUDI KELAYAKAN PENDIRIAN RADIO EDUKASI
}

Oleh: Innayah *)

\section{Abstrak}

Radio edukasi adalah radio yang memanfaatkan dunia pembelajaran, dimana pola atau ruang lingkup pembelajaran ialah pendidikan formal, nonformal, yang meliputi pembelajaran. Dengan format radio pendidikan dan informasi (jauh berbeda dengan siaran-siaran radio lain yang cenderung lebih besar porsinya kepada siaran hiburan), radio pendidikan mampu menarik perhatian audiens yang haus akan informasi pendidikan. Media radio mempunyai sifat sosial dan pendengar yang heterogen. Maka untuk pendirian sebuah radio edukasi diperlukan legitimasi melalui studi kelayakan dengan mengadakan jajak pendapat pada masyarakat sekitar dengan radius $5 \mathrm{~km}$ dari lokasi Radio edukasi dengan mempertimbangkan sifat heterogenitas pendengar radio. Penelitian ini diadakan pada tanggal 7 - 9 Februari 2007 . Dengan tujuan mendapatkan data yang berupa pendapat, masukan maupun saran yang berkaitan dengan radio edukasi/ pendidikan. Kenyataan di lapangan, masyarakat menginginkan adanya radio pendidikan dengan menampilkan acara yang menarik dan dikemas secara kreatif dengan konsep radio yang matang.

Kata kunci : Radio Edukasi, Survey/studi kelayakan, Pendirian

\section{A. PENDAHULUAN}

Media radio identik dengan indera pendengaran. Informasi atau pesan yang disampaikan dituangkan ke dalam lambang auditif sehingga media ini memiliki pengaruh yang kuat terhadap pendengarnya. Radio merupakan media yang dinamis dan dapat mengikuti perkembangan zaman. Hal ini selaras dengan fungsi radio sebagai media hiburan dan informasi. Informasi sewaktuwaktu selalu berubah, setiap hari bahkan bisa berubah hanya dalam hitungan detik. Fungsi media yang seperti ini yang dipandang efektif dan mempunyai sumbangan yang besar dalam kemajuan pendidikan di negara kita. Dunia pendidikan juga selalu menuntut sesuatu yang baru, informasi yang aktual sesuai dengan tuntutan dunia pendidikan.
Biro Statistik tahun 1995 menunjukkan 94\% penduduk Indonesia mendengarkan radio, dan $69,4 \%$ dari total penduduk di Indonesia memiliki pesawat radio sendiri (Masduki, 2001). Penelitian wave 4 tahun 2007, ratarata pendengar radio di 7 kota besar di Indonesia termasuk Yogyakarta sebesar 56 \% (MUNAS XII 2008). Ini menunjukkan bahwa Radio sampai saat ini masih mempunyai peranan yang cukup besar di masyarakat walaupun mengalami penurunan pendengar.

Radio merupakan media massa yang mempunyai fungsi seperti dikatakan Laswell dan Wright, yaitu melakukan pengamatan sosial (social surveillance), menghubung

*) Innayah S.Sos., adalah tenaga fungsional peneliti bidang pendidikan pada Balai Pengembangan Media Radio Yogyakarta (BPMR)-Pusat Teknologi Informasi dan Komunikasi Pendidikan (Pustekkom)-Kemdiknas. 
kelompok satu dengan lainnya (social correlation), melakukan transformasi nilai dari satu generasi kepada generasi berikutnya (socialization), dan menghibur (entertainment). Keempat fungsi itu sering disederhanakan menjadi tiga saja, yaitu informatif, edukatif, dan menghibur. Akan tetapi pada dewasa ini sebagian besar siaran radio swasta di Yogyakarta hanya mengedepankan program acara hiburan (Darmanto, kompas.com) padahal program acara yang baik mestinya merupakan implementasi fungsi media massa tersebut.

Yogyakarta merupakan kota pendidikan dan barometer pendidikan di Indonesia. Dengan demikian dapat dikatakan bahwa sebagian besar masyarakat Yogyakarta adalah pelajar. Dari banyaknya radio komersial di Yogyakarta yang berjumlah 44 radio, 1 radio public (RRI) dan 40 radio komunitas (www.kpiddiy.com) belum ada satupun yang menyiarkan program khusus pendidikan. Padahal saat ini pendidikan nasional masih dihadapkan pada beberapa permasalahan yang perlu ditangani secara serius. Permasalahan tersebut antara lain, kualitas relevansi pendidikan yang masih rendah dan lemahnya manajemen pendidikan. Pemerintah telah bertekad untuk mengatasi permasalahan tersebut dengan berbagai cara. Penyelesaian konvensional yang telah dilakukan selama ini ternyata belum mampu sepenuhnya mengatasi permasalahan tersebut. Oleh karena itu, diperlukan usaha yang memadukan dan memanfaatkan perkembangan ilmu pengetahuan dan teknologi dengan memanfaatkan sember daya pendidikan.

Dalam menghadapi tantangan tersebut, Balai Pengembangan Media Radio (BPMR) sebagai unit pelaksana teknis Pusat Teknologi Informasi dan Komunikasi Pendidikan Kementerian Pendidikan Nasional melalui SK Mendiknas Nomor 103/O/2003 berupaya mendukung pemecahan permasalahan tersebut terutama yang berkaitan pada pemerataan kesempatan memperoleh pendidikan dan peningkatan mutu, relevansi dan daya saing.
Sehubungan dengan hal tersebut, BPMR berupaya mendirikan sebuah stasiun siaran khusus pendidikan yang bernama Radio Edukasi. Dimana ruang lingkup siarannya meliputi pembelajaran formal, nonformal, dan informasi kebijakan untuk masyarakat pendidikan maupun masyarakat yang tertarik pada dunia pendidikan. Informasi pendidikan formal memuat materi-materi pelajaran yang diperuntukkan bagi siswa tingkat SD, SMP, dan SMA sesuai kurikulum yang berlaku.

Sementara informasi pendidikan nonformal memuat nilai-nilai luhur yang ada dalam kehidupan masyarakat Indonesia sehari-hari, baik itu nilai-nilai agama, budaya, etika, dan sosial, maupun untuk meningkatkan kemampuan di bidang-bidang tertentu, misal: lembaga pelatihan dan kursus. Radio edukasi ini dikembangkan dengan pola sajian yang mendidik, interaktif, dan menghibur. Interaktif yaitu memberi kesempatan pada audiens untuk mengekspresikan idenya secara lisan maupun tertulis dalam berbagai aktivitas fisik dan mental. Dengan demikian keberadaan Radio Edukasi dapat diharapkan sebagai sumber belajar baru bagi masyarakat, khususnya masyarakat Daerah Istimewa Yogyakarta.

Landasan pendirian Radio Edukasi dengan mempertimbangkan seperti disyaratkan pendirian sebuah radio pada umumnya, yaitu dengan mempertimbangkan adanya UndangUndang Republik Indonesia Nomor 32 Pasal 4 ayat 1 tahun 2002 tentang Penyiaran, yang berbunyi penyiaran sebagai kegiatan komunikasi massa mempunyai fungsi sebagai media informasi, pendidikan, hiburan yang sehat, kontrol dan pererat sosial.

Pertimbangan lain adalah Undang-Undang Republik Indonesia Nomor 36 Bab 1 pasal 1 tahun 1999 tentang Telekomunikasi. Pada ketentuan umum disebutkan bahwa pemancar radio adalah alat telekomunikasi yang menggunakan dan memancarkan gelombang radio. Oleh karena itu untuk memperoleh pengakuan (legitimasi) tentang pendirian radio edukasi tersebut perlu dilakukan survey jajak pendapat guna menjaring pendapat, masukan dan saran dari masyarakat sekitar terkait akan berdirinya stasiun Radio Edukasi. 
Berpijak dari latar belakang di atas, maka permasalahan yang akan coba diungkap, yaitu:

1. Bagaimana pendapat masyarakat sekitar perihal rencana pendirian stasiun radio edukasi.

2. Bagaimana masukan dan saran dari masyarakat sekitar Yogya terkait dengan program acara dalam radio edukasi.

Penelitian ini bertujuan adalah:

1. Untuk memperoleh data tentang pendapat masyarakat sekitar Yogya perihal rencana pendirian stasiun radio edukasi

2. Untuk memperoleh data tentang masukan dan saran dari masyarakat sekitar Yogya terkait dengan program acara dalam radio edukasi

\section{B. KAJIAN LITERATUR}

Di Indonesia, radio merupakan alat komunkasi penting sejak negara ini baru berdiri. Kepemilikan pesawat radio meningkat dengan pesat, hingga mencapai setengah juta yang berlisensi pada pertengahan 1950an. Radio digunakan secara luas di bidang Pendidikan, terutama pendidikan politik, seperti mempersiapkan calon pemilih untuk pemilu pertama pada 1955. Indonesia yang merdeka mengikuti kebijakan pemerintah Jepang dalam hal monopoli siaran. Sampai terbentuknya Orde Baru, terdapat 39 stasiun RRI diseluruh Indonesia,menyiarkan kepada lebih dari satu juta radio berlisensi.(M. Mufid:2007).

Radio merupakan salah satu sumber bahan ajar yang ekonomis, menyenangkan, dan mudah disiapkan serta dapat berfungsi sebagai media pembelajaran untuk belajar mandiri. Dengan kemasan materi yang menarik akan merangsang daya imajinasi dan kreatvitas anak, sehingga mereka akan terlihat aktif. Media ini juga dapat membantu bagi audience yang mengalami buta huruf, karena penyajiannya mengandalkan audio, suara, atau bunyi. (Erna YulikahError_Cluck@Yahoo.Co.Id.Peran Radio Pendidikan).
Menurut Dodi Mawardi (2008) dalam Dunia radio.com, radio memiliki 9 karakteristik, yaitu

1. Theater of Mind yaitu media radio memiliki kemampuan untuk membangkitkan imajinasi pendengar.

2. Personal yaitu media radio mampu menyentuh pribadi pendengar

3. Sound only yaitu media radio hanya menggunakan media suara dalam menyajikan informasinya.

4. At Once yaitu media radio dapat diakses cepat dan seketika

5. Heard Once yaitu media radio didengar secara sepintas.

6. Secondary Medium Half Aers Media yaitu media radio hanya bisa menjadi teman dalam beraktifitas

7. Mobile/portable yaitu media fisik radio mudah dibawa kemana saja.

8. Local yaitu media radio bersifat lokal, hanya di daerah yang terjangkau frekwensinya.

9. Linear yaitu media radio tersusun secara sistematis.

Siaran radio untuk pendidikan pertama dikembangkan oleh Pusat Teknologi Informasi dan Komunikasi Pendidikan (Pustekkom)-Kementerian Pendidikan Nasional (Kemdiknas) dengan nama Diklat SRP. Diklat SRP ini merupakan Kegiatan perintisan pengembangan dan pemanfaatan program siaran radio untuk pendidikan dan pelatihan guru-guru Sekolah Dasar melalui Siaran Radio. Perintisan penyelenggaraan Diklat SRP ini dilakukan di Yogyakarta dan Semarang berdasarkan rekomendasi berbagai hasil studi yang dilaksanakan (Miarso dan Suhedi, 1984).

Radio pendidikan adalah radio yang memanfaatkan dunia pembelajaran, dimana pola atau ruang lingkup pembelajaran ialah pendidikan formal, nonformal, yang meliputi pembelajaran. Dengan format radio pendidikan dan informasi (jauh berbeda dengan siaran-siaran radio lain yang cenderung lebih besar porsinya kepada siaran hiburan), radio pendidikan mampu menarik perhatian audiens yang haus akan informasi pendidikan. Misal dalam pelajaran 
berbahasa, radio berfungsi untuk menimbulkan motivasi untuk belajar baik sendiri maupun berkelompok, juga untuk memobilisasikan pendapat dan meningkatkan daya imajinasi anak. (http://yustina.blog.upi.edu/category/ uncategorized/hasil-seminar/).

Menurut A. Darmanto (2005) dalam Himpunan Materi Pelatihan Bidang Radio Siaran, kelebihan media radio pendidikan adalah:

1. Rapidity yaitu tingkat kecepatan menyampaikan informasi cukup tinggi

2. Wide Coverage yaitu jangkauan wilayah siarnya luas.

3. Simultaneous (dapat dinikmati secara srentak dalam waktu yang sama).

4. Mempunyai kemampuan mengembangkan imajinasi melalui audio.

5. Selektivitas dalam memilih program/ segmen khalayak.

6. Fleksibilitas yaitu dapat dibawa kemanamana.

7. Bersifat personal (hubungan yang terasa intim dengan penyiarnya.

8. Verbalisme (ada pengucapan, intonasi, diksi, dan lain-lain).

9. Beyond emotion.

10. Sound and amoving image.

11. Show Performing Art.

12. Literacy (dapat dinikmati oleh khalayak yang buta huruf)

Dengan demikian media radio pendidikan merupakan media penyampaian informasi secara cepat yang memiliki jangkauan luas dan dinikmati banyak orang yang program siarannya dipilih secara selektif mudah dibawa kemana-mana, menimbulkan rasa intim atau dekat dengan penyiarnya dan dapat dinikmati oleh khalayak yang buta huruf.

Sedangkan kekurangan media radio pendidikan menurut $A$. Darmanto dalam Program Pendidikan Sekolah Melalui radio adalah:

1. Auditif (Sekilas dengar).

2. Tidak dapat disimak ulang untuk memperjelas.

3. Tidak dapat menyajikan permasalahan yang kompleks (rumus matematika, fisika, kimia).
4. Tidak efektif untuk materi yang bersifat hitung-menghitung.

5. Tidak dapat menggambarkan proses perubahan benda (Fisika, Kimia).

6. Tidak bisa menyajikan materi secara mendalam.

7. Tergantung daya tarik penyajian program.

Dengan demikian radio pendidikan mempunyai sifat sekilas dengar, sehingga tidak dapat disimak ulang untuk memperjelas dan tidak dapat menyajikan permasalahan yang kompleks untuk materi yang bersifat hitung-hitungan. Disamping itu radio pendidikan tidak bisa menyajikan materi secara mendalam. Agar pendengar lebih tertarik untuk memanfaatkan atau mendengarkan perlu adanya daya tarik dalam penyajian program.

Selanjutnya Fungsi Siaran Radio Pendidikan A. Darmanto dalam Program Pendidikan Sekolah Melalui radio adalah:

1. Meningkatkan kesadaran nasional warga negara.

2. Modernisasi nasional

3. Suplemen bagi pendidikan sekolah

4. Mempercepat penyampaian informasi baru tentang pendidikan kepada sekolah.

5. Penyelenggaraan pendidikan bagi semua kalangan dengan isi yang sama untuk skala nasional.

6. Menggantikan fungsi kehadiran guru profesional dan profesor.

7. Menambah materi pengajaran dan bacaan buku,

8. Modernisasi dalam penyampaian materi dan mengembangkan metode mengajar.

9. Mengikuti pendidikan kembali bagi guruguru.

10. Mencukupkan informasi dan pendidikan bagi kelompok kecil.

11. Membantu mereka yang tidak mampu melanjutkan sekolah karena tidak memiliki waktu dan keterbatasan ekonomi.

12. Persiapan belajar untuk menghadapi ujian nasional.

Dari beberapa kelemahan dan kekurangan serta fungsi siaran radio pendidikan tersebut, maka media radio pendidikan dapat memungkinkan untuk upaya menyukseskan pendidikan dengan menjadikan media radio 
sebagai media pendidikan bukan dijadikan sebagai media hiburan. Sehingga media radio dapat dimanfaatkan oleh berbagai publik yang haus akan informasi pendidikan atau pengetahuan.

Radio Edukasi BPMR Yogyakarta sengaja dirancang untuk menyajikan materi-materi pendidikan serta informasi dunia pendidikan yang dikemas secara mendidik, interaktif dan menghibur.

\section{METODOLOGI}

Metode penelitian yang digunakan adalah survey melalui jajak pendapat. Penelitian survey merupakan penelitian yang mengumpulkan informasi dari suatu sample dengan menanyakan melalui angket atau interview agar nantinya menggambarkan sebagai aspek dari populasi (Yatim Riyanto dalam Nuzul Zuriah, 2005). Penelitian Survey melalui jajak pendapat ini di gunakan untuk mengetahui respon publik akan berdirinya radio edukasi. Permohonan persetujuan publik berarti polling yang bertujuan untuk meminta legitimasi atau persetujuan publik terhadap satu isu atau persoalan atau fakta tertentu yang terjadi di masyarakat (Metode Penelitian Komunikasi, http://massofa.wordpress.com).

Adapun populasi dalam survey ini adalah masyarakat sekitar kantor BPMR Yogyakarta dengan radius $5 \mathrm{~km}$ yang berjumlah 261 responden. Sampel diambil dengan teknik purposive random sampling, yaitu sampel diambil secara acak pada populasi dengan tujuan tertentu.

Sampel pada penelitian survey ini yaitu :

1. Warga masyarakat Sorowajan Baru Banguntapan Bantul.

2. Warga masyarakat Pelem Banguntapan Bantul.

3. Warga masyarakat Nogopuro Yogyakarta

4. Warga masyarakat Celeban Yogyakarta

5. Warga masyarakat Gedongkuning Yogyakarta

Penelitian survey melalui jajak pendapat ini berlangsung selama 3 hari yaitu pada tanggal 7 - 9 Februari 2007.
Pengumpulan data dengan cara memberikan angket kepada masyarakat sekitar kantor BPMR Yogyakarta. Angket berisi pertanyaan tertulis dengan responden diminta menjawab pertanyaan di tempat yang telah disediakan. Analisis yang digunakan deskriptif kualitatif. Yang dimaksud dengan analisis ini adalah hasil penelitian beserta analisisnya diuraikan dalam suatu tulisan ilmiah yang berbentuk narasi kemudian dari analisis yang telah dlakukan diambil suatu kesimpulan (http:// www.skripsi.tesis.com)

\section{HASIL DAN PEMBAHASAN}

Tuntutan masyarakat yang semakin besar terhadap pendidikan serta kemajuan ilmu pengetahuan dan teknologi, membuat pendidikan tidak mungkin lagi dikelola hanya dengan pola tradisional, disamping cara ini tidak sesuai lagi dengan kebutuhan dan tuntutan masyarakat. Revolusi ilmu pengetahuan dan teknologi, perubahan masyarakat, pemahaman cara belajar anak, kemajuan media komunikasi dan lainnya memberi arti tersendiri bagi kegiatan pendidikan dan tuntutan ini pulalah yang membuat kebijakan untuk memanfaatkan media teknologi pendidikan dan pendekatan teknologis dalam pengelolaan pendidikan. Radio Edukasi merupakan salah satu media teknologi pendidikan yang sengaja dirancang sebagai sumber belajar. Dimana keberadaanya juga mempertimbangkan peran ideal radio sebagai media publik yaitu mewadahi sebanyak mungkin kebutuhan dan kepentingan pendengarnya. Kebutuhan itu adalah kebutuhan informasi, pendidikan, dan hiburan (Masduki, 2001 : 2). Radio Edukasi sebagai sumber belajar berupaya mefungsikan kembali peran ideal radio tersebut dengan menitik beratkan penyiaran pada program pendidikan.

Pendengar radio adalah massa, artinya sejumlah orang yang sangat banyak yang sifatnya heterogen, terpencar-pencar di berbagai tempat, di kota dan di desa, di rumah, pos tentara, asrama, warung kopi, dan sebagainya. Ini berarti antara pendengar yang satu dengan pendengar yang lainnya berbeda dalam jenis kelamin, usia, pekerjaan, 
agama, pendidikan, kebudayaan, ideologi, hobi, pengalaman, pandangan hidup, cita-cita dan lain sebagainya. (Onong Uchjana Effendy, 1991: 17). Berdasarkan hal tersebut pendirian Radio Edukasi juga harus disesuaikan dengan sifat heterogen pendengar. Ditinjau dari ilmu komunikasi heterogenitas seperti itulah yang menyebabkan media massa (radio) menetapkan acara tertentu secara khusus untuk berbagai kelompok diatas dengan tujuan agar setiap individu terpuaskan (Onong Uchjana Effendy, 1991 : 17).

Radio Edukasi sebagai media massa telah melakukan survey khalayak berdasarkan usia, pendidikan dan pekerjaan. Dengan ini acara yang disiarkan diharapkan dapat memberikan kepuasaan bagi pendengarnya. Hasil yang diperoleh dari pengambilan data melalui penyebaran angket jajak pendapat terhadap 270 responden pada radius $5 \mathrm{~km}$ sekitar berdirinya Radio Edukasi Yogyakarta tentang pendirian radio edukasi/pendidikan dari jumlah 261 angket yang terkumpul (9 angket tidak kembali) dapat dijabarkan sebagai berikut:

\section{Usia}

Dilihat dari umur responden sejumlah 261 orang memperlihatkan bahwa : responden yang berusia antara $13-23$ tahun berjumlah 98 orang, yang berusia antara $24-34$ tahun berjumlah 72 orang, yang berusia antara 35 - 45 tahun berjumlah 35 orang, yang berusia antara 46 - 56 berjumlah 32 orang, yang berusia antara 57 - 67 tahun berjumlah 20 orang dan yang berusia antara 68 - 78 tahun berjumlah 3 orang. Untuk responden yang tidak mengisi daftar umur yaitu 1 orang. Melihat uraian umur tersebut di atas maka umur responden bervariatif antara 13 tahun sampai dengan 78 tahun. Sedangkan mayoritas responden didominasi umur antara 13 - 23 tahun yaitu yang berjumlah 98 orang atau 38 $\%$, dimana pada usia tersebut masih pada taraf mengenyam dunia pendidikan/ bersekolah.
Adapun diagram batangnya dapat dilihat di bawah ini :

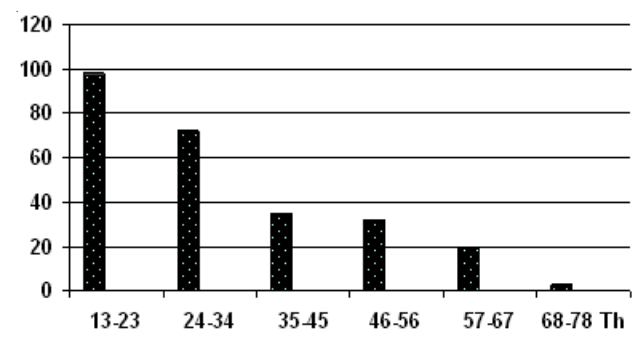

Diagram 1. Sebaran Umur Responden

\section{Pendidikan}

Ditinjau dari segi latar belakang pendidikan responden maka dapat dijabarkan bahwa responden yang berlatar belakang pendidikan SMP berjumlah 34 orang, berlatar belakang pendidikan SMA dan sederajat berjumlah 103 orang, berlatar belakang pendidikan D1 berjumlah 5 orang, berlatar belakang pendidikan D2 berjumlah 15 orang, berlatar belakang pendidikan D3 berjumlah 24 orang, berlatar belakang pendidikan S1 berjumlah 70 orang, berlatar belakang pendidikan S2 berjumlah 3 orang dan berlatar belakang pendidikan S3 ada 1 orang. Sedangkan yang tidak mengisi latar belakang pendidikannya sejumlah 6 responden. Dari uraian di atas menunjukkan bahwa latar belakang pendidikan responden bermacam - macam mulai dari tingkat SMP sampai dengan S3. Untuk latar belakang pendidikan yang menonjol/ paling banyak dari rensponden yaitu yang berlatar belakang S1 yang berjumlah 70 orang atau $27 \%$.

Untuk lebih menjelaskan dapat dilihat pada diagram batang berikut ini :

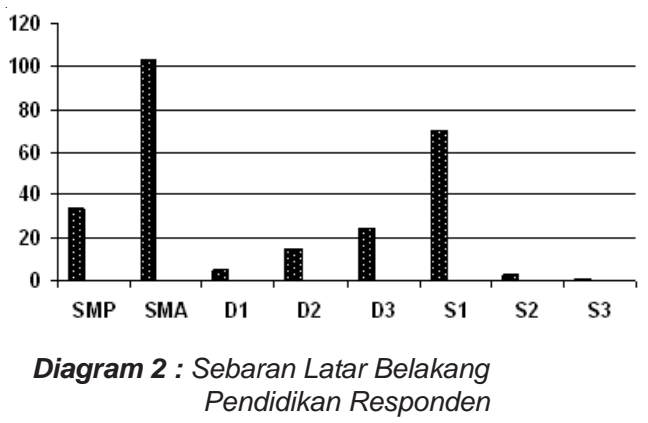




\section{Pekerjaan}

Ditilik dari latar belakang pekerjaan responden dapat dijabarkan sebagai berikut : Responden yang berlatar belakang pekerjaan pensiunan/ purnawirawan berjumlah 17 orang. Responden yang berlatar belakang pekerjaan mahasiswa berjumlah 72 orang, responden berlatar belakang pekerjaan pelajar 34 orang, berlatar belakang pekerjaan swasta/karyawan berjumlah 61 orang, yang berlatar belakang pekerjaan wiraswasta berjumlah 17 , sedangkan yang berlatar belakang pekerjaan PNS berjumlah 17 orang. Adapun responden yang berlatar belakang pekerjaan guru berjumlah 20 orang, dan berlatar belakang pekerjaan dosen 2 orang serta responden yang berlatar belakang pekerjaan ibu rumah tangga berjumlah 12 orang. Sedangkan responden yang tidak mengisi jenis pekerjaannya berjumlah 9 orang. Dengan demikian responden yang berlatar belakang pekerjaan mahasiswa mendominasi jumlah responden yaitu 72 orang atau $28 \%$.

Dalam diagram batang dapat dilihat di bawah ini :

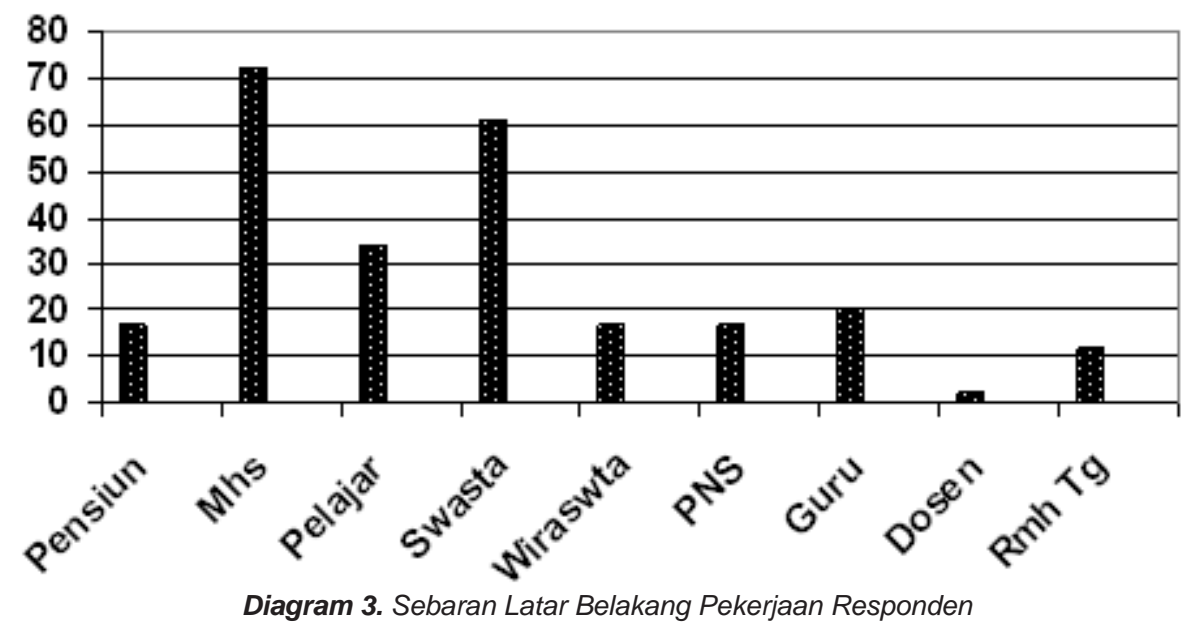

\section{Persetujuan}

Hasil angket jajak pendapat menunjukkan bahwa dari 261 responden yang menyatakan persetujuan berdirinya radio edukasi/pendidikan berjumlah 250 orang dengan alasan yang dapat dirangkum sebagai berikut : radio edukasi/ pendidikan setuju untuk berdiri karena berkaitan dengan dunia pendidikan seperti menambah pengetahuan, membantu belajar, memberantas kebodohan, dan menunjang pendidikan, yang kesemuanya dapat disimpulkan bahwa radio edukasi/pendidikan disetujui untuk didirikan dengan alasan akan mendukung program pendidikan. Sedangkan 11 responden mengemukakan ketidak setujuannya akan berdirinya radio edukasi/pendidikan dengan alasan : tidak efektif, pemborosan, anak sudah capek sepulang sekolah, pelajaran disekolah saja tidak masuk apalagi diradio.

Dengan demikian dapat disimpulkan bahwa pendirian radio edukasi/ pendidikan Yogyakarta mendapat persetujuan dari 250 orang yang bermukim disekitar lokasi radio edukasi dengan radius $5 \mathrm{~km}$. Jika dikorelasikan dengan persyaratan pendirian radio yang dikeluarkan oleh KPID Yogyakarta yang menyatakan bahwa untuk mendirikan sebuah stasiun radio diperlukan persetujuan minimal 250 orang yang bermukim disekitar stasiun radio yang akan didirikan, maka persyaratan tersebut telah dipenuhi/terpenuhi untuk mendirikan stasiun radio edukasi/pendidikan. 
Adapun diagram batangnya dapat dilihat di bawah ini :

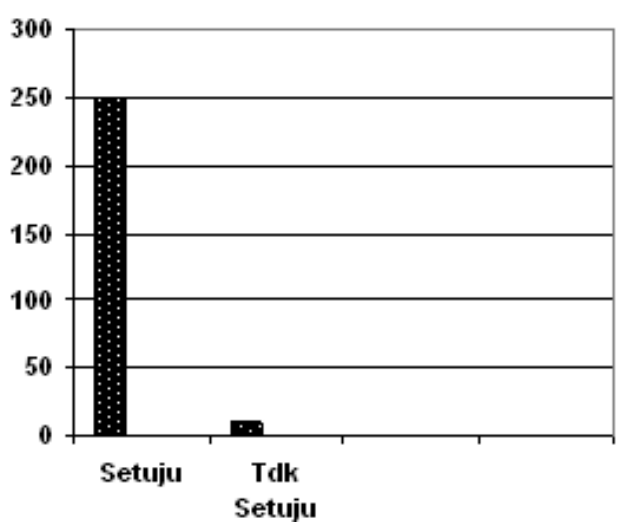

Diagram 4. Pendapat Responden Tentang Pendirian Radio Edukasi

\section{Program Acara Usulan Responden}

Untuk program acara radio edukasi/ pendidikan yang diusulkan responden sangat bervariatif, namun demikian hampir semua usulan program dari responden sudah terwadahi oleh program acara yang akan disiarkan/dikemas oleh radio edukasi/pendidikan yaitu pendidikan, informasi/berita, hiburan dan iklan penunjang. Hanya saja usulan dari responden kebanyakan terkait dengan model ataupun jenis - jenis siarannya, seperti hiburan meliputi musik, tembang jawa, cerita cinta, zodiac, dan lain sebagainya. Sedangkan program pendidikan meliputi pendidikan bahasa Jawa, kesehatan, English dan Iain sebagainya.

\section{Model siaran pendidikan}

Ada banyak masukan terkait dengan model siaran program pendidikan radio edukasi/pendidikan, namun demikian dari masukan-masukan tersebut dapat ditarik kesimpulan terkait dengan model siaran pendidikannya. Model yang diusulkan oleh responden terkait siaran program pendidikan yaitu model interaktif, tanya jawab dan kuis pendidikan. Sedangkan terkait dengan penyampaiannya responden memberi masukan agar disampaikan/disiarkan secara komunikatif, inovatif, humoris, tidak membosankan, variatif, menarik dan mudah dipahami.

\section{Waktu siaran program pendidikan}

Untuk waktu/jam siaran program pendidikan radio edukasi/pendidikan, responden memberi banyak masukan yaitu : antara jam 06.00 - 08.00 WIB berjumlah 35 orang, antara jam 08.00 10.00 WIB berjumlah 7 orang, antara jam 10.00 - 12.00 WIB 0 orang, antara jam 12.00 - 14.00 WIB berjumlah 4 orang, antara jam $14.00-16.00$ WIB berjumlah 41 orang, antara jam $16.00-18.00$ WIB berjumlah 93 orang, antara jam 18.00 20.00 WIB berjumlah 40 orang dan antara jam $20.00-22.00$ WIB berjumlah 31 orang. Dari waktu/jam yang diusulkan oleh responden, maka untuk siaran program pendidikan mayoritas responden ( 93 orang/36 \% ) mengusulkan antara jam 16.00 - 18.00 WIB dimana pada jam tersebut merupakan waktu luang diluar jam pelajaran di sekolah.

Dalam diagram batangnya adalah sebagai berikut :

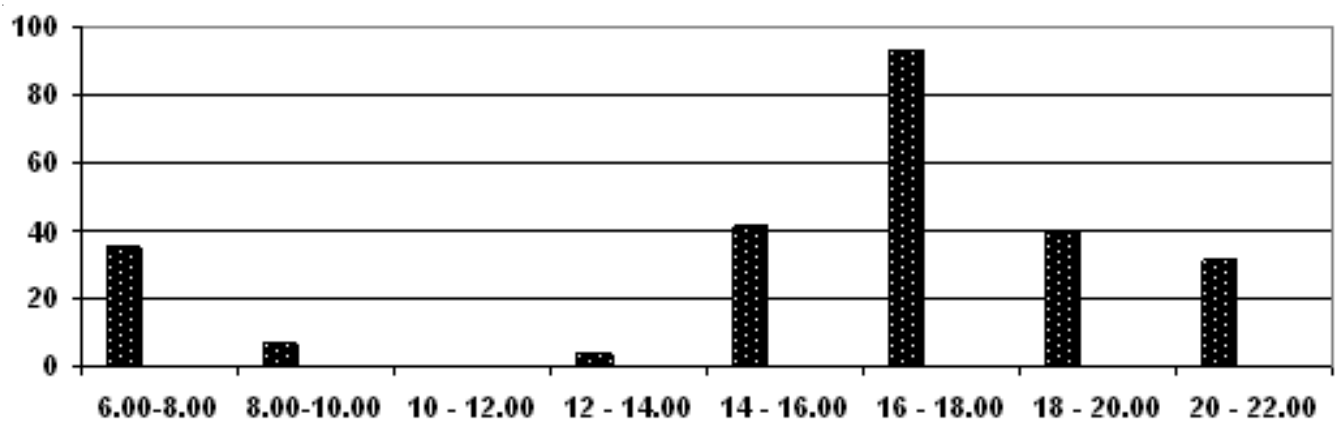

Diagram 5. Sebaran Waktu/Jam Siaran Program Pendidikan 
8. Usulan Program informasi/berita

Responden yang memberi masukan terkait dengan siaran program acara informasi/berita radio edukasi/pendidikan dapat disimpulkan bahwa semua responden (100\%) mengusulkan bahwa untuk acara program informasi/berita menyiarkan informasi yang up to date dan aktual terkait dengan masalah ekonomi, pendidikan, sosial, budaya keamanan, lingkungan, iptek, agama, bencana dan lowongan pekerjaan.

\section{Usulan Program Acara Hiburan}

Adapun untuk siaran program acara hiburan radio edukasi/pendidikan dapat disimpulkan bahwa responden mengusulkan acara hiburan yang meliputi: permainan, musik, cerita, konsultasi cinta, kuis, reques lagu dan gossip selebriti.

\section{Pengisi Acara/Partisipan}

Dari total responden yang mengisi angket, 138 orang atau $53 \%$ menyatakan kesiapannya untuk mengisi acara/tampil di siaran radio edukasi. Sedangkan 68 orang atau $26,8 \%$ menyatakan ketidaksediaannya untuk mengisi acara/ tampil pada radio edukasi. Sedangkan sisanya yang berjumlah 55 orang atau $20,2 \%$ tidak memberikan jawaban/ abstain.

Adapun diagram batangnya dapat dilihat di bawah ini :

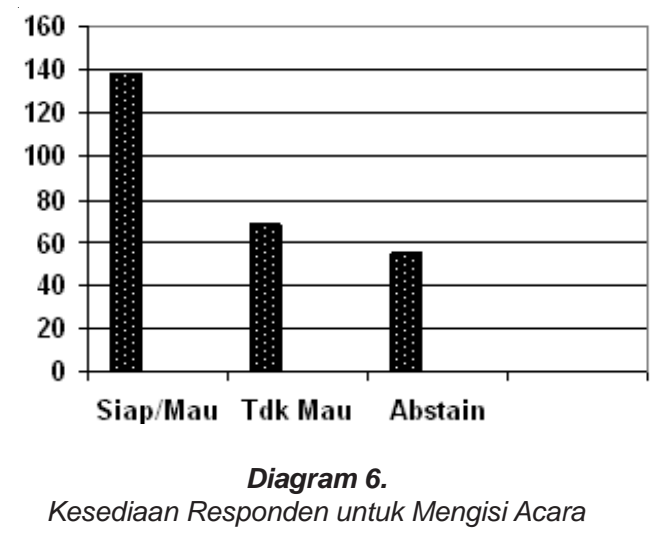

\section{E. KESIMPULAN DAN SARAN}

\section{Kesimpulan}

Berdasarkan penelitian dapat ditarik kesimpulan sebagai berikut:

1. Pada umumnya responden setuju dengan berdirinya radio edukasi dengan alasan karena materi siarannya berkaitan dengan dunia pendidikan seperti menambah pengetahuan, membantu belajar, memberantas kebodohan, dan menunjang pendidikan, yang kesemuanya dapat disimpulkan bahwa radio edukasi/pendidikan disetujui untuk didirikan dengan alasan akan mendukung program pendidikan.

2. Program acara radio edukasi/pendidikan yang diusulkan responden sangat bervariatif, namun demikian hampir semua usulan program dari sudah terwadahi oleh program acara yang akan disiarkan/dikemas oleh radio edukasi/ pendidikan yaitu pendidikan, informasi/ berita, hiburan dan iklan layanan masyarakat.

a. Model yang diusulkan responden terkait siaran program pendidikan yaitu model interaktif, tanya jawab dan kuis pendidikan dengan disampaikan/ disiarkan secara komunikatif, inovatif, humoris, tidak membosankan, variatif, menarik dan mudah dipahami.

b. Pada umumnya responden ( 93 orang/36 \% ) menginginkan siaran program pendidikan dilaksanakan antara jam $16.00-18.00$ WIB dengan alasan pada jam tersebut merupakan waktu luang diluar jam pelajaran di sekolah.

c. Pada umumnya responden mengusulkan program acara hiburan radio edukasi/pendidikan meliputi : permainan, musik, cerita, konsultasi cinta, kuis, reques lagu dan gossip selebriti.

d. Untuk program acara partisipasi radio edukasi, responden (138 orang atau 53\%) menyatakan kesiapannya untuk mengisi acara/tampil di siaran radio edukasi. 


\section{Saran}

1. Radio Edukasi hendaknya disajikan acara yang menarik dan kreatif sehingga dapat meningkatkan minat pendengarnya.

2. Bahasa yang digunakan hendaknya tidak terlalu formal yaitu bahasa tutur, bahasa keseharian audience jadi kesannya lebih santai tetapi tetap serius.

3. SDM pengelola diharapkan yang berkualitas.

4. Waktu siar sebaiknya setelah jam belajar sekolah.

5. Informasi atau berita pendidikan yang diharapkan yang up to date.

6. Sarana prasarana radio edukasi hendaknya yang memadai (genset, pemancar tidak bocor hingga mengganggu siaran TV, dll ),

7. Radio Edukasi perlu diperluas jangkauannya tidak hanya di wilayah Yogyakarta.

8. Perlu sosialisasi program-program radio ke sekolah-sekolah untuk menunjang pembelajaran.

9. Program siaran disesuaikan dengan sasaran kebutuhan pendengar.

10. Perlu menjalin kerjasama dengan sekolah dan radio-radio lainnya.

11. Program-program pendidikan yang disiarkan lebih banyak ke pendidikan formal.

\section{DAFTAR PUSTAKA}

Uchjana Effendy. M.A.Onong.1991. Radio Siaran Teori dan Praktek. Manda Maju.Bandung Sumitro, dkk. _..Pengantar Ilmu Pendidikan. Yogyakarta : FIP YOGYAKARTA

M a s d u k i. 2001 . J u r n a l i s t i k Radio.LPKIS.Yogyakarta.
A. Darmanto. 2005.. Himpunan Materi Pelatihan Bidang Radio Siaran

Erna Yulikah-Error_Cluck@Yahoo.Co.Id.Peran Radio Pendidikan

M. Mufid.2007.Komunikasi dan Regulasi Penyiaran.Jakarta. Kencana Prenada Media Group

Naskah Akademik Radio Edukasi.2007.Balai Pengembangan Media Radio (BPMR) Yogyakarta

www.kpi.go.id 10 Maret 2010. UU RI Nomor 32 tahun 2002 tentang Penyiaran.

www.postel.go.id 10 Maret 2010 Undang-Undang Republik Indonesia Nomor 36 tahun 1999 tentang Telekomunikasi.

Departemen Pendidikan dan Kebudayaan. 1983. Teknologi Instruksional. Jakarta: Ditjen Dikti, Proyek Pengembangan Institusi Pendidikan Tinggi.

Danim Sudarwan. 2008. Media Komunikasi Pendidikan. PT. Bumi Aksara.Jakarta.

Arsyad Azhar.1996.Media Pembelajaran.PT. Raja Grafindo Persada.Jakarta

Metode Penelitian Komunikasi.http:// massofa.wordpress.com/2008/02/24/ penelitian-komunikasi/

http://cetak.kompas.com/read/xml/2009/09/29/ 13311934/Menyoal.Kualitas.Siaran.Radio.Di.

Yogyakarta

Dunia radio.2008.Media Radio dan Saran Radio Pendidikan.http://duniaradio.blogspot.com/ 2008

Miarso, Yusufhadi dan Suhedi. (1984). "Perkembangan Kelembangaan Pusat Teknologi Komunikasi Pendidikan dan Kebudayaan" dalam Haryono, Anung,dkk (eds), (1984). Teknologi Komunikasi Pendidikan : Pengertian dan penerapannya di Indonesia. Jakarta : Pusat Teknologi Komunikasi Pendidikan dan KbudayaanDepartemen Pendidikan dan Kebudayaan. 